\title{
Tammy Chang, MD, MPH, MS Selected as 2017 National Academy of Medicine Puffer/ABFM Fellow
}

\section{Jane Ireland}

The National Academy of Medicine (NAM) has selected Tammy Chang, MD, MPH, MS as the 2017 James C. Puffer, MD/American Board of Family Medicine Fellow. Dr. Chang is an assistant professor in the Department of Family Medicine at the University of Michigan-Ann Arbor. She is 1 of 5 outstanding health professionals selected for the class of 2017 NAM Fellows.

Dr. Chang received her undergraduate degree from the University of

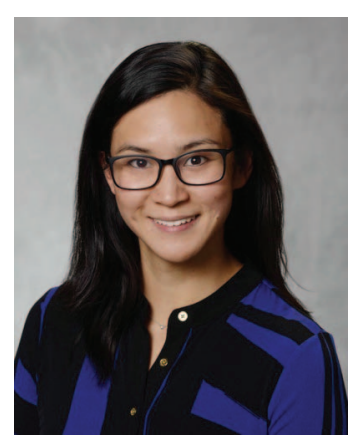
Michigan with honors in cellular and molecular biology and zoological anthropology. She also received her medical degree and master of public health degree in health policy and management from the University of Michigan. Dr. Chang completed residency training and served as cochief resident in the Department of Family Medicine at the University of Michigan and is an alumna of the University of Michigan Robert Wood Johnson Foundation Clin-

Conflict of interest: The author is an employee of the ABFM. ical Scholars program. She has received several national awards including the Academy Health Presidential Scholarship for New Health Services Researchers, the North American Primary Care Research Group Distinguished Trainee Award, and the Society of Teachers of Family Medicine Distinguished Article Award.

As a Puffer/ABFM/NAM Anniversary Fellow, Dr. Chang will receive a research stipend of $\$ 25,000$. Named in honor of James C. Puffer, MD, president and chief executive officer of the ABFM, the fellowship program enables talented, early-career health policy and science scholars in family medicine to participate in the work of the Academies and further their careers as future leaders in the field. The James C. Puffer, MD/ABFM Fellowship was established under the NAM Fellowship program in 2011.

NAM Anniversary Fellows continue their main responsibilities while engaging part time over a 2-year period in the Academies' health and science policy work. A committee appointed by the president of the Institute of Medicine (IOM) selects fellows based on their professional accomplishments, potential for leadership in health policy in the field of family medicine, reputation as scholars, and the relevance of their expertise to the work of NAM and the IOM. 